The University of Southern Mississippi

The Aquila Digital Community

Faculty Publications

2016

\title{
The Maternal Personhood of Cattle and Plants at a Hindu Center in the United States
}

Daniel S. Capper

University of Southern Mississippi, Daniel.Capper@usm.edu

Follow this and additional works at: https://aquila.usm.edu/fac_pubs

Part of the Hindu Studies Commons, and the Personality and Social Contexts Commons

\section{Recommended Citation}

Capper, D. S. (2016). The Maternal Personhood of Cattle and Plants at a Hindu Center in the United States. Pastoral Psychology, 65(4), 427-441.

Available at: https://aquila.usm.edu/fac_pubs/14852

This Article is brought to you for free and open access by The Aquila Digital Community. It has been accepted for inclusion in Faculty Publications by an authorized administrator of The Aquila Digital Community. For more information, please contact Joshua.Cromwell@usm.edu. 
This article appeared in Pastoral Psychology 65:4 (2016): 427-441.

\title{
The Maternal Personhood of Cattle and Plants at a Hindu Center in the United States
}

Daniel Capper ${ }^{1}$

\begin{abstract}
Religious experiences with sacred nonhuman natural beings considered to be "persons" remain only vaguely understood. This essay provides a measure of clarification by engendering a dialogue between psychoanalytic self psychology on one side and, on the other, religious experiences of cattle and Tulsi plants as holy mothers at a Hindu cattle sanctuary in the United States. Ethnographic data from the Hindu center uncover experiences of sacred maternal natural beings that are tensive, liminal, and colored with affective themes of nurturance, respect, and intimacy, much like psychoanalytic maternal selfobjects. Devotees protect cattle and ritually venerate plants because these actions facilitate a limited experiential grounding of religiosity on what is perhaps the most fundamental of all relationships, the relationship with the mother, within a theological worldview that somewhat embraces nonhuman natural beings in both doctrine and practice.
\end{abstract}

\section{Keywords}

Cow protection, Selfobject, Personhood, Plant veneration, Psychoanalysis

\footnotetext{
${ }^{1}$ D. Capper

University of Southern Mississippi

118 College Drive, \#5015

Hattiesburg, MS 39406

E-mail: Daniel.Capper@usm.edu

Phone: 601-266-4522
} 
For his book People Trees: Worship of Trees in Northern India, David L. Haberman spent a year in India ethnographically studying the sometimes intimate experiences that many contemporary Hindus have of pipal, neem, and banyan trees considered to be sacred. In the course of his study, Haberman found that prevailing academic methods regarding animism and tree worship, which are still shaped by 19th-century scholars like Edward Tylor, James Frazer, and W. Robertson Smith, prevented him from fully entering and comprehending the worldviews of the humans he studied. Arguing that tree worship "is a matter of cultural 'difference,' not an encounter with 'the primitive mind"' (Haberman, 2013, p. 189), Haberman did not treat trees as just objects with whom a meaningful human relationship is impossible. His study required him to understand that for his informants, including those who were cosmopolitan and highly educated, trees can be "persons" very much like humans. He writes,

Tree worshipers in India clearly presume that they are in the presence of a discerning being who can hear their praises and petitions, be moved by their offerings, and is capable of having a significant impact on their lives.... Trees are considered to be sentient beings; they are animate life forms endowed with feelings and consciousness.... Trees, in short, are influential persons not radically separate from the human world; on the contrary, trees and humans share enough characteristics in common to make significant interaction and relationship possible. (Haberman, 2013, pp. 185-187)

Because of this, Haberman (2013) says, "Many tree worshipers informed me, 'Trees are persons just like you and me'" (p. 191). In so doing, he offers us a welcome methodological challenge to broaden our horizons and reconsider the notion of natural beings, including plants, as persons. 
In insisting on a methodological recognition of the attributed personhood of nonhuman natural beings, Haberman joins many scholars across diverse fields, including religious studies (Berry, 2006), philosophy (Derrida, 2008), psychology (Melson, 2001), anthropology (Hallowell, 1960), neuroscience (Berns, 2013), and even ethology, where an increasing number of animal studies experts such as Franz de Waal (1996) and Marc Bekoff (2007) embrace this recognition in their own work. In the ethnographic study of a Hindu center in the United States that I present here, I too find explicit and implicit understandings of personhood being extended to a variety of natural entities, most especially cattle and the tulsi plant, although this time in the United States, not India. Further, my data throw light on religious experiences of Hindus born in the United States with natural entities not just as persons but specifically as mothers. These data provide new interpretive challenges for the psychology of religion. How might human religious experiences with a sacred cow differ, or not differ, from religious experiences with other humans or a fully nonmaterial deity? What do experiences of the attributed personhood of holy plants teach us about human psychology?

In the past the psychology of religion somewhat understandably has focused primarily on human-with-human or human-with-nonmaterial-god religious experiences, but this situation has left us without tools for comprehending religious experiences with natural entities like sacred maternal bushes or cattle. Currently we possess few psychoanalytic studies of human religious interactions with the nonhuman natural world broadly conceived, much less of a specific notion like sacred maternal natural entities. Adams (1999), Alper (1993), and Brown $(2004,2007)$ helpfully have applied psychoanalytic self psychological theory to human-animal interactions, yet their works do not include religion nor do they explore elements of the natural world beyond the animal kingdom, such as plants. Plants also remain overlooked in Melsen's (2001) study of 
child development and animals, as she repeatedly described plants simply as "inanimate," an account not shared by the Hindus in Haberman's study, my informants in this study, and members of many other forms of religion.

In this article I explore the psychological reality of the maternal personhood attributed to sacred natural beings by bringing together the genres of psychoanalysis and religious studies to create a dialogue between psychological theory and empirical Hindu realities. From psychoanalytic self psychology I utilize the concept of the selfobject and its understanding of the inner experiences of motherhood. From religious studies I probe ethnographic material arising from ten weeks of field work in autumn 2014 at New Talavana Dham, a Hindu cattle sanctuary in the southern United States. This material reveals themes in which, from a self psychological point of view, devotees appear to experience, with some limits, holy natural beings as good maternal selfobjects who in the ideal facilitate the psychological processes of mirroring and idealizing that provide essential human health.

In following this path I marry psychoanalysis and religious studies through an approach that diverges from many pursuits in the psychology of religion. Here, I utilize the selfobject as a research heuristic rather than as a clinical diagnostic tool, much as was done in studies by Browning (1987) and Schlauch (1999). I unfold the selfobject in a religious environment to discover theoretical implications, and then, using these implications as a Gadamerian "horizon" (Gadamer, 1989), I fuse in dialogue the horizon of psychoanalysis with the horizon of New Talavana realities. As a result, this dialogue will foreground religious encounters in which cattle and the tulsi plant are experienced in ways that, like the experience of a good human mother selfobject, are tensive, liminal, and affectively oriented toward themes of nurturance, maternal 
worthiness of respect, and intimacy. Unfortunately the nature of my data precludes discerning whether these experiences facilitate deep structural or merely compensatory changes.

I am not now nor have I ever been a Hindu or a member of ISKCON, the larger organization to which New Talavana belongs. I studied the New Talavana community because of the vividness and distinctiveness of its religious interactions with the natural world. I wished to study relationships with sacred cattle, and New Talavana hosts the largest cattle sanctuary in the United States. Moreover, the center also offered an opportunity to conduct an ethnography of religious experiences with plants, as currently there are few ethnographies of this genre.

Members of the community were generally welcoming and always tolerant of me as I respectfully participated in some communal chanting practices but mostly simply observed, although I also interviewed as many community members as I could. Although some New Talavana members are immigrants from India, the interview data that I report in this essay come exclusively from practitioners born and raised in the United States, all of whom are of European descent except for one second-generation American of Indian descent. I framed discussions by telling devotees that I found their beliefs and practices toward the natural world to be interesting, and many devotees then happily shared their experiences. Sometimes I broke interpersonal ice by sharing that I cared for a pet cow as a child.

First, I will describe my self psychological approach to the material. Then, I will discuss Mother Cow, Mother Tulsi, and devotees' experiences of them before providing a synthetic analysis.

\section{Self Psychology and maternal selfobjects}


Several decades ago, psychoanalysis underwent a revolution as thinkers spurned classical Freudian notions in favor of substantially overhauled theories and practices. One of the most important elements of this movement involved the establishment of psychoanalytic self psychology, which was originally formulated by Heinz Kohut and continues to be extended by current analysts. Unlike Freudian theory that focused on instinctual drives, self psychology emphasizes relationships, making it both more interactive and more culturally flexible than earlier forms of psychoanalytic thought and practice.

Self psychology revolves around the concept of the selfobject. Selfobjects constitute a foundation for the self by providing experiential frameworks for channeling strong affectivity. Kohut (1991) described selfobjects as "inner experiences of certain functions of people who, extrospection informs us, are physically separate from them" (p. 494). A selfobject is an experience of a relationship in which another being, object, symbol, or idea provides essential psychological functions for the self. A parent or partner cannot be a selfobject, but the experience of a parent or partner can be (Wolf, 1988, p. 52), so that rather than saying that a person is a selfobject, one should say that a person incites selfobject experiences.

Arising from relationships, selfobject experiences provide essential psychological functions and therefore channel powerful affectivity. A brief friendship that dissolves may leave us relatively unaffected, as selfobject interactions were lacking, whereas the loss of an intimate long-term relationship may arouse strong affect because of the influential selfobject experiences involved. This depth lends the selfobject experience the ability to aid or hinder self-cohesion, stability, and well-being. Since the "self-sustaining function of selfobject experiences is needed for life" (Wolf, 1988, p. 53), human health rises or falls with the intense nature of the selfobject experience. Because of its foundational character and inherent relationality, the selfobject 
represents a pivotal concept that makes self psychology more interactive than classical psychoanalysis.

As indivisible parts of the self, intrapsychic selfobject experiences mediate between the inner world and the outer world, between first-person subjective reality and the social realm, and remain experienced as a part of both worlds while being reducible to neither. Occupying the psychological "betwixt-and-between" space of the inner self and outer being and thus representing a "liminal" experience in Victor Turner's (1969) terms, the selfobject mediates firstperson experiences of other beings, objects, symbols, or ideas. The selfobject lacks sharp boundaries between self and other, as instead it embodies a tensive experience of a psychological space that arises ambiguously as neither-self-nor-not-self. As such, the selfobject remains nondual; thinking in terms of the subject/object split misses the psychological point of the selfobject (Schlauch, 1999, p. 62). Of course cultures define boundaries between self and other in different ways, but the selfobject will always occupy the psychological middle ground.

Because the selfobject provides essential psychological functioning, humans encounter selfobject experiences from cradle to grave, although selfobject experiences alter their forms with maturity (Wolf, 1988, p. 53). For children, selfobject relationships tend to revolve around parents, siblings, and other family members, whereas adult selfobject experiences extend beyond the family to include almost any being, object, symbol, or idea.

Due to fundamental human psychological needs for mirroring, idealizing, and peer relationships, there exist three types of selfobjects. The need to be valued and admired and to receive approval for qualities and accomplishments manifests as a need for mirroring selfobjects that relationally meet this need and therefore aid the establishment of worthwhile ambitions. The need to admire beings and values for their positive qualities, such as a teacher worthy of 
emulation, results in relationships with idealized selfobjects that engender self-esteem and guiding principles through interactions with an admired other. The need to feel valued through similarity with others reflects a twinship need that finds outlets for satisfaction through group membership selfobjects, leading ideally to the development of talents and skills.

As a child's first fans, mentors, and playmates, parents —in particular, mothers—serve as the original and primary providers of twinship and especially mirroring and idealizing selfobject experiences. Through their powerful selfobject imprints, parents influence their offspring throughout the life cycle. Parental responses that offer experiences of both nurturance for the child's activities as well as admirable parental character to idealize supply the psyche with healthy mirroring and idealizing selfobject experiences. Conversely, the failure of parents to nurture the child's activities obstructs the development of healthy ambitions, and the failure of parents to offer themselves as genuine role models inhibits the development of healthy idealizing relationships with both people and values. Further, what parents do matters less than who they are, especially in terms of the parents' intimate, empathic characters; a child bathed in intimate empathy can survive traumatic experiences without undue damage, whereas a child lacking in empathic parental responses struggles to develop a cohesive self even in the absence of traumatic events (Kohut, 1971, pp. 64-65). Because of these features, in the self psychological ideal the child experiences positive liminal selfobject relationships with the mother that are affectively colored with themes of mirroring nurturance, maternal worthiness of respect for idealizing, and empathic intimacy.

A wide variety of stimuli may incite selfobject experiences, including "religious experiences, group experiences, scientific and philosophic insights, and the like" (Kohut, 1971, 64), or shape a concept of God (Holliman, 2002). Thus, there exist places for many forms, 
including sacred forms, in the experiences of selfobjects, and, according to recent studies, this does not exclude a variety of nonhuman natural beings. Alper (1993) suggests that pets, particularly when considered part of a family, may provide vital selfobject functions of mirroring, idealizing, and affective regulation for children from households where humans provide poor selfobject resources. Similarly, Adams (1999) argues that Emily Dickenson's dog Carlo provided her with important mirroring, idealizing, and twinship selfobject resources that inspired and soothed Dickenson during the period of her greatest poetic productivity. Such animal selfobject experiences can be more powerful than those with humans (Brown, 2004, p. 71) because animals "do not criticize, retaliate, feel overwhelmed, or reject" (Alper, 1993, p. 259). Although Sue-Ellen Brown (2004) says that it remains uncertain whether such selfobjects can engender deep structural changes to the self or are simply compensatory, the power of such selfobject experiences should not be doubted, as "sometimes a companion animal may be a person's strongest link to life itself' (p. 83). In this way, the concept of the selfobject helps to explain why people may feel special bonds with certain animals. Animal selfobject experiences are commonly of the mirroring type, but they can also be idealizing, and twinship selfobject relationships with animals are surprisingly common (Brown, 2007; Melson, 2001). Of interest in relation to the argument below regarding the plant goddess Tulsi, Alper (1993, p. 265) states that such positive selfobject experiences can arise even with animals like goldfish that often are considered relatively nonresponsive. 
Not all natural forms necessarily elicit selfobject experiences, but some do. ${ }^{2}$ The New Talavana cattle sanctuary offers examples in which cattle and Tulsi plants function as if they were inciting maternal selfobject experiences. I now turn to New Talavana.

\section{Mother Cow and Mother Tulsi}

The founding of my field location, New Talavana Dham, followed the establishment of a Hindu ISKCON (International Society for Krishna Consciousness) temple in New Orleans in 1971. Some of the new devotees wished to forsake the city for the countryside so that they could protect cattle to please and serve their monotheistic deity Krishna (Kṛṣna). In scriptures such as the Bhāgavata Purāna, Krishna takes the appearance of human form both on earth and in the highest heaven, Goloka-Vrndāvan, specifically so that he may enjoy herding cattle, his favorite animal. New Talavana religion features numerous tales that idealize the life of Govinda, or

${ }^{2}$ Gail F. Melson (2001, pp. 117-118) explores several cases of animal-assisted therapy with children in which a child fails to respond to many possible animal selfobjects yet still develops a special bond with a particular animal, showing how individualized natural world selfobject experiences can be. Why humans respond as they do in this way remains understudied and hence unclear. Of course, New Talavana energetically promotes conscious devotional attitudes toward cattle and Tulsi, thus structuring human encounters with nature from the outset. When I asked New Talavana devotees whether they also reverenced other natural beings beyond cattle, Tulsi, and other entities promoted by the tradition such as holy Indian rivers, every devotee responded in the negative. Thus, at least among the devotees with whom I spoke, New Talavana teachings, rituals, and lifestyles tend to produce a fixed canon of natural selfobject choices. 
Krishna the cowherd, ${ }^{3}$ and offers plentiful encouragement for practitioners of the religion similarly to embrace intimate, spiritual relationships with cattle.

Devotees purchased a rural property in southern Mississippi in 1974. The 1,200-acre farm encompasses longleaf pine forest, wetlands, wheat fields, fruit orchards, residential space, and a goshala (gośālā), or cattle sanctuary. The goshala provides a never-slaughter health care resource and retirement home for the revered cattle that provide the raison d'etre for New Talavana.

New Talavana religion derives from the Madhva Gaudiya Vaiṣnava lineage of Indian Hinduism. This lineage began with Caitanya Mahāprabhu (1486-1534 CE), a charismatic saint who led an important revival of bhakti, or devotional, Hinduism. Caitanya's emphasis on the practice of chanting Krishna's name trickled through various spiritual teachers in eastern India until it reached A. C. Bhaktivedanta Swami Prabhupāda, who was tasked by his guru Bhaktisiddhānta Saraswatī with spreading Caitanya's message to the English-speaking world. Arriving in New York City in 1965, Prabhupāda quickly created and then expanded the organization of ISKCON. Today, four hundred ISKCON centers exist on every continent but Antarctica. Like Caitanya, devotees chant the name of Krishna in the form of the Mahā-mantra taught to them by Prabhupāda: "Hare Krishna, Hare Krishna, Krishna Krishna, Hare Hare / Hare Rama, Hare Rama, Rama Rama, Hare Hare." This mantra has resulted in the nickname of "Hare Krishnas" for the group.

This Indian pedigree lends New Talavana spirituality a type of openness to the nonhuman natural world that may not exist in all religions. Scholar of Indian religions Harold Coward

\footnotetext{
${ }^{3}$ Many scholars have studied Krishna as a cowherd, notably Edwin F. Bryant (2003), David L. Haberman (1994), and David R. Kinsley (1977).
} 
(2000) tells us, "In contrast to the Western traditions where humans are frequently described as being separate from nature over which they have dominion, Indian thought has seen humans (in their embodied lives) as an intimately interconnected part of nature" (p. 39). We get a sense of the lively holy regard this tradition has for natural beings when we consider scriptural passages in which Caitanya's charisma made tigers and deer kiss each other due to their religious euphoria (Prabhupāda, 2014a, n.p.) and Krishna caused enraptured clouds to expand and trees to tremble from spiritual ecstasy (Prabhupāda, 2014b, n.p.). ${ }^{4}$ Thus, David Haberman (2006) says, "One need only travel about India to observe reverence toward natural forms: the worship of mountains, forests, animals, trees, ponds, rocks, plants, and rivers as natural forms of divinity" (p. 38). As noted above, he specifically says of Hindu reverence for trees, "They are powerful 'persons' (vyakti)—certainly animate, sentient beings with feelings and consciousness with whom one can communicate and establish meaningful, mutually beneficial relationships" (Haberman, 2013, p. 155). This religious sense of relative openness to the nonhuman natural world invites the development of selfobject experiences with natural beings.

Part of ISKCON's early expansion included the establishment of farm communities to teach and live ISKCON's motto, "Simple living and high thinking," emphasizing goshala cow protection, sustainable organic production, and natural lifestyles. There are 60 ISKCON farms across the globe, including five others in addition to New Talavana in the United States. Probing

\footnotetext{
${ }^{4}$ There exist a number of fine translations of the scriptural texts that I cite. Here, I will use the same paper and electronic translations of scriptures that devotees use in order to share the most authentic rasa or flavor of New Talavana spirituality.
} 
why these farms emphasize cow protection provides helpful instruction regarding some Hindu attitudes toward cattle. ${ }^{5}$

Contrary to common misunderstandings, Hindus do not protect cattle because they consider them to be manifest deities like the Apis Bull in ancient Egypt or cattle totems among current eastern African groups such as the Maasai. Since they are just animals, not gods, Hindu cattle ritually may become temporary deities, but this divine status remains transient. The goddess of prosperity Lakșmī may inhabit the bodies of cows, yet bovines, in themselves, persist without divinity. Sometimes elaborate offerings are made to Nandī, the holy bull, but this is mostly because Nandī mediates interactions with the central deity Śiva, not so much because of Nandī himself (Zeiler, 2013, p. 133). Hindus may reverence the magical wish-fulfilling surabhi cow Kāmadhenu, but this goddess of the cow remains mostly unimportant in Indian religions as she lacks significant organized worship or temples of her own. New Talavana's temple altar contains images of cattle, as do devotee's homes, but these serve as symbolic reminders of Krishna rather than as images of divinities. At New Talavana one would not wish to worship cattle as deities, anyway, since New Talavana ideologically regards humans as spiritually superior to animals, plants, and other natural beings. As temple President Yogindra Vandana Das

\footnotetext{
${ }^{5}$ Hindu cattle protection has been studied by a variety of scholars, including William Crooke (1912), Paul Diener, Donald Nonini, and Eugene E. Robkin (1978), Stanley A. Freed and Ruth S. Freed (1981), Marvin Harris (1966, 1974), Alan Heston (1971), Frank J. Korom (2000), Deryck O.Lodrick (1981), and Deryck O. Lodrick (2005).
} 
Adhikari told me, "Only humans know how to become liberated from suffering. Animals cannot do so because they eat, sleep, and so on, without a deeper understanding." ${ }^{\prime 6}$

Instead, devotees offered me two primary reasons for protecting cattle, the first arising from the theological urge to serve Krishna. In this form of Hinduism, practitioners do not merge into oneness with the godhead, as may happen with other forms of the tradition. Rather, devotees seek dualist service of Krishna in passionate and loving ways. To be an ISKCON member is to be a servant of Krishna, as is clear in the religious names of initiates, all of which end in "Dasi" or "Dasa," the female and male terms, respectively, for "servant."

Krishna cares for his beloved cattle and specifically asks us to do the same, so devotees should serve him by loving and protecting them, too. As Krishna taught, devotees should treasure the pañcagavya, the five great products of the cow: milk, butter, curd, urine (for medications), and dung (in India, for cooking, heating, home construction, medications, and other uses). Moreover, cattle enjoy regard as Krishna's supreme animals, as the scriptural Mahäbhärata tells that cattle, "guileless in their behavior," arise superior even to gods like Brahmā, make the best gift, cleanse one of sin, and are "the foremost of all things." Further, devotees say that the highest nonhuman animal rebirth is as a cow or bull, with big cats and primates just below. So, as longtime devotee Mayapur Dham Dasa plainly put it, "To put

\footnotetext{
${ }^{6}$ I should mention that the superiority of humans within New Talavana theology remains mitigated somewhat by the realities of Hindu reincarnation. The souls of all living beings remain essentially the same across transmigrations, and species identity arises as a temporary rebirth outcome since I may be a human in this life but a cat in my last life and a lizard in my next life. In this way, species identity is important in New Talavana theology, as my informants stressed, but species differences in some ways remain a matter of degree rather than of kind.
} 
Krishna at the center of your life is to put cows at the center of your life, since Krishna loved cows so." This connection to Krishna helps to explain why Vaiṣnava Hindus tend to be more active in their cow protection than other Hindus.

The second reason devotees give for protecting the cow emerges not just at New Talavana; it also represents the views of Hindus from many sects and even some Indian nonHindus. Following perspectives that may be traced in part to the Vedas, humans possess seven mothers, all of whom are holy and should be protected: the birth mother, the wife of the spiritual teacher, the wife of the king, the wife of a brähmaṇa or member of the highest caste, a nurse, the earth, and Go Mātā or Mother Cow (Prabhupāda, 1971, p. 60). Like a good human mother, Mother Cow provides food, medicine, and other forms of nurturance. Also like a good human mother, Mother Cow aids humans in fulfilling their potential. Because of this, casual, everyday discourse at New Talavana explicitly recognizes cows as spiritual mothers and emphasizes the need to offer cattle respect, devotion, and gratitude.

The protection of cows due to respect for their membership in the holy Seven Mothers offers a window into maternal selfobject experiences at New Talavana. As with the neither-menor-not-me selfobject, the experience of Mother Cow is tensive and liminal, as she is like humans in her maternal nature yet remains spiritually inferior to humans. Cattle are thought to inhabit the closest realm of rebirth to humans and thus are like us, yet they also remain a separate species. This liminality appears along with the concomitant themes of maternal nurturance (her aid to survival), worthiness of respect (because of her gifts), and her immanent, intimate sacredness. Thus, New Talavana's concept of Mother Cow as one of the Seven Mothers appears to reflect experiences of cattle as maternal selfobjects. 
Just as most people would shrink from cannibalizing their human mother, so at New Talavana the experience of the cow as mother leads to a prohibition on eating beef, as seen in the oft-found ISKCON question, "How can you eat your mother?” Indeed, since humans are so intimate with animals such as Mother Cow, New Talavana prohibits eating all animal flesh and its members practice thoroughgoing vegetarianism. We get a sense of the relative selfobject importance of animals when we consider that the eating of plants is not prohibited; devotees explain the lack of protection of plants on the grounds that plants appear less like humans, specifically in terms of lacking the central nervous systems of humans and animals. Put differently, New Talavana appears to practice vegetarianism because animals, and especially Mother Cow, like selfobjects, are liminally experienced as enough like us to outlaw their consumption but simultaneously are not like us, as their species affiliations lead to the question of menu choice in the first place.

Remarks made by a long-term devotee who lives at New Talavana, Mayapur Dham Dasa, make apparent this connection between vegetarianism and a liminal maternal selfobject. Mayapur said,

The cow is one of our Seven Mothers who nurture us. Who gives milk to all humankind? Who is so generous and loving? Especially dairy cows, they have those big, beautiful eyes ... they are persons [rather than things].

All over the world people are relishing the flesh of the cow. But she's so sweet and loving and innocent, with big lotus eyes. The cows, they're completely on another level. If we could be as humble as a cow, that would be amazing. 
We just want people to understand, they don't have to eat the cow. There are other ways to eat and still get more protein than you need. Eating a cow is as bad as you can be, it is the most sinful thing that you can do.

Long-time devotee Kaivalya Sundari Dasi echoes Mayapur's account of the cow as one of the Seven Mothers, and, as far as she is concerned, eating cattle, whom she intentionally refers to as "persons," not only approaches cannibalism because of the cow's motherhood, it also causes many problems:

Meat eating is the biggest cause of our calamities, whether they're natural disasters or whether they're wars, because meat eaters are racking up negative karma big time. It's a cycle that gets bigger and bigger and then hits hard. All that karma has an impact on things that happen to us. So if we [in ISKCON] are not part of that equation of the violence of meat-eating, we're relatively protected. We don't agree with all of that violence, the killing of animals, or mistreating animals. Mohanasini, an experienced devotee who lives on a houseboat near New Talavana, likewise connects vegetarian non-harm with maternal perceptions of cattle:

We have dominion over animals, but this doesn't mean that we can slaughter them. We should take care of them. What do cattle give us? Mother Cow gives us milk, butter, cheese, ghī [clarified butter] for cooking, and even the dung can be made into flat patties for cooking fuel, as they do in India. And the ox tills the field. So they give us so much more alive than you get by killing them. But this vegetarianism does not just show respect for Mother Cow, it also remains enabled in part through her maternal nurturing activities. The community's cattle sanctuary maintains a small herd of dairy cows that provides the community with about nine gallons of 
fresh milk daily. Devotees consume the milk not just in liquid form but also in homemade Indian-style paneer cheese, the sweet treat burfi, and other forms. This consumption of dairy products vitally adds protein and healthy animal fats to the vegetarian New Talavana diet. In this way, Mother Cow nurtures her devotees by helping to make their vegetarian lifestyle possible, and devotees openly revere Mother Cow for this. So New Talavana vegetarianism reveals liminal, tensive relationships with animals, in particular the cow, with relationship themes of maternal nurturing nutrition, protective respect, and intimacy through consumption of food gifts, similar to what one would find with a maternal selfobject.

As I have mentioned, in order to enjoy the nurturing fruits of Mother Cow as well as to protect cattle from the slaughter that is the norm for American bovines, New Talavana houses a goshala, or "cattle sanctuary." Goshalas provide retirement homes and clinical facilities for cattle, giving care to cattle who are too old or infirm to be productive and therefore might be destroyed, which remains an acute danger for both dairy and meat cattle in the United States.

New Talavana's herd originated in the 1970s when a devotee purchased a Holstein cow and her calf at a livestock sale. These two females provided the reproductive basis for the herd, although Jersey cattle were bought later for the higher buttermilk content of their milk. Several Zebus, an Indian breed, were transferred from the ISKCON New Vrindaban farm in West Virginia. A non-devotee vegetarian donated a cow, and a beef-breed cow joined the herd after being found wandering in New Talavana's forest. Devotees have purchased milk cows when necessary to improve the herd's genetic dynamics. Eighty-eight surplus cattle were also given to New Talavana by other ISKCON farms where cattle protection resources did not match the enthusiasm of devotees for cow protection. Typically, the New Talavana herd consists of about one hundred cattle at any one time, although due to the many recent deaths of cattle added to the 
herd in the 1990s, there were only 68 cattle at the time of my field work. Today most of the herd members are enjoying their golden years, with many cattle in the 15- to 23-year-old age group. The ox Ishana at 23 is the oldest of all. Two calves were born during the time I was at New Talavana.

Exhibiting their attributed personhood, all cattle bear Sanskrit names with religious meanings. Over time, name lineages have emerged, with the longest current lineage being Surabhi the Fifth. Following New Talavana's never-slaughter philosophy, cattle die only natural deaths. Devotees ritualize these occasions by bringing food, water, and decorative garlands to a dying cow or ox and chanting with the bovine. ${ }^{7}$

Caring for the herd requires significant financial resources. New Talavana leaders recognize that running a goshala in the United States is an economically irrational exercise, as devotees expend capital resources on cattle that will never provide a significant return on the investment. New Talavana finances its cow protection through donations, primarily through its Adopt-a-Cow program. It also raises money for cow protection when it gratefully thanks cattle at Gopāștamī, the autumn holy day that marks when Krishna the boy cowherd went with the cows to the fields for the first time. At New Talavana, this occasions one of the largest public celebrations of the year, the Festival of the Cow.

\footnotetext{
${ }^{7}$ Some commentators criticize Hindus when they do not offer what some would consider to be compassionate euthanization for elderly cattle. I lack space here to enter this argument genuinely. However, I should mention that many humans avoid euthanizing their human mothers, similar to the Hindu avoidance of euthanasia of cattle, thus providing another contact point between maternal humans and maternal Mother Cow.
} 
Every year about seven hundred and fifty people, a relatively large gathering for a nonmainstream religion in the Bible Belt, come to New Talavana for the Festival of the Cow. Devotees array the temple, main pavilion, and central grounds with decorations and adorn themselves with their most festive Indian clothing. Large posters of individual New Talavana cattle, complete with their names, appear all over the central grounds, as do booths that raise money for cow protection by selling books, CDs, organic home-canned foods, freshly squeezed sugar cane juice, spiritual accessories like crystals, tarot card readings, and Indian village food cooked authentically over burning cow dung.

In a pen near these booths, devotees place a gentle cow to enable cow veneration. Children at the event seem to enjoy this presence of Mother Cow as a fun petting zoo. But adult devotees, being more solemn in their approach, show their reverence by ritually marking her face with vermillion powder, as one may do for a human or deity, and offering her a ritually blessed flower garland of honor. Then they show devotion and respect as well as gain good karma by petting the cow and softly saying to her, "Go Mata ki jai" or "Glory to Mother Cow!" For her part, the tame cow, accustomed to human interaction, seems to somewhat enjoy being the center of attention, perhaps accepting admiration like a good idealized maternal selfobject.

In these ways, New Talavana's cattle sanctuary engenders experiences that seem to reflect those of maternal selfobjects. The goshala protects cattle in the first place because bovines attract human respect for their nurturing qualities while remaining, as I have discussed, simultaneously both like and unlike humans. And, on the basis of nurturing and respect, devotees relate to cattle through experiences of intimacy, including caresses of celebrated cattle at a festival as well as providing hospice care for bovines. The community rejoices over cattle births and mourns their demises. New Talavana devotees interact with their cattle not as objects living 
on a commercial farm but as subjects with names, personalities, and agendas of their own. Thus, in the religious practice of maintaining a cattle sanctuary, one finds the themes of human nurturance, respect, and intimacy in liminal relationships with natural beings, much as one would find with a human maternal selfobject.

Mother Cow's nurturing through the provision of dairy products does more than satisfy vegetarian nutrition requirements, as I discussed before; it also helps to make possible a foundational devotional practice of this school, the "honoring" or consuming of prashadam (prasādam), or food blessed by being first ritually offered to Krishna. During the ritual offering, Krishna consumes the food only with his glance, leaving plenty for everyone else. Then, as Bhagavad Gïtā 3.13 says, "The devotees of the Lord are released from all kinds of sins because they eat food which is offered first for sacrifice" (Prabhupāda, 1986, p. 160). Proper religious practice means that all of one's food should be prashadam, which one "honors" rather than "eats" out of gratitude and respect for the gifts of both Krishna and Mother Cow. Honoring prashadam is not just delicious, it is a fundamental way that one can serve Krishna, earning ISKCON the nickname of "the kitchen religion." Anyone who consumes prashadam, even an animal, gains the guarantee of at least a human rebirth in the next life. By providing nurturing protein as well as dairy flavor, Mother Cow helps to make this practice possible.

But despite Mother Cow's contribution to the essential practice of honoring prashadam, she does not represent the most important sacred natural mother in this practice, as no offering enjoys acceptability without the presence of Śrīmatī Tulasī Devī, or Honored Mother Goddess Tulsi, also known as the holy basil plant. Krishna will not accept and bless food that lacks the presence of Tulsi (Ocimum sanctum L.), so all prashadam offerings must consist in part of her, even if only old and withered Tulsi is available. Because of this, all New Talavana offering 
plates include fresh Tulsi leaves, blessed water is made from infusions of Tulsi mañjarīs or buds, and cooks utilize fresh Tulsi in creating devotee prashadam. As a goddess wife of the deity Viṣnu, unlike other plants eaten at New Talavana, Tulsi freely sacrifices herself for ritual consumption out of her compassion. By consuming Tulsi one integrates her spirit as one of Krishna's foremost disciples. Moreover, devotees believe her wood provides a protective talismanic function, especially for the human head, so they utilize Tulsi wood rosaries in rituals as well as wear Tulsi wood necklaces at all times.

Mother Tulsi represents an example of the investment of religious meaning in some of the plants found in Indian religions. For example, the nīm tree provides nonlethal organic pesticide, many medicines, and a home for Śitala, the goddess who battles smallpox and creates prosperity for her devotees (Haberman 2013, pp. 137-138). Followers of the Hindu deity Śiva create their rosaries from the seeds of the holy rudrākșa tree (Elaeocarpus ganitrus). The famous pipal or bo tree (Ficus religiosa) provides residences for a variety of deities, especially Viṣnu, so burning its wood is taboo for some. Further, because the Buddha realized enlightenment under one of these trees, Buddhists often make rosaries from its seeds and may even reverence it (Haberman 2013, pp. 101-103). Venerated all over India, Tulsi has her own religious festival, Tulsi Vivah, and her own famous temple, the Tulsi Manas Mandir in Varanasi, India (Upadhyaya, 1964, p. 21). Since her presence is thought to bring longevity and happiness, she is often grown in the courtyards of Indian homes.

The scriptural Skanda Purāna states, "Tulasī is auspicious in all respects. Simply by seeing, simply by touching, simply by remembering, simply by praying to, simply by bowing before, simply by hearing about or simply by sowing this tree, there is always auspiciousness" (Prabhupāda, 1970, p. 100). In addition, in ISKCON Tulsi's title, "Śrīmatî" or "Honored 
Mother," connotes the idea of divine motherhood, and one of her maintenance prayers directly addresses her maternally: "I am bathing goddess Tulsi Devi, who is very dear to Govinda [Krishna] and who brings life to all the devotees. She is the mother of the universe, and the bestower of devotion to Lord Krishna." Like a caring mother she protects, leads from sin, sponsors growth, and enables activities, and devotees recognize this maternal side in experiencing her as a divine person rather than a stationary object.

Early every morning, devotees reverence and show their gratitude to Tulsi through a $p \bar{u} j \bar{a}$ (worship service) dedicated to her. During this service, practitioners sing many beautiful songs and repeatedly intone the Mahā-mantra. A püjāri, or temple priest, places a potted Tulsi plant on a high stand right in front of the temple's main altar while the chanting continues. When I attended, Tulsi was healthy, vigorous, and about 18 in. $(46 \mathrm{~cm})$ tall. Her pot features a lovely maroon velvet cover with sequins and a gold silk lining, indicating her importance and majesty. The priest then sets up a $p \bar{u} j \bar{a}$ altar on a lower stand next to Tulsi. After this, devotees sing the

\section{Tulasī-pūjā-kīrtana:}

O Tulasī, beloved of Krishna, I bow before you again and again. My desire is to obtain the service of Śrī Śrī Rādhā and Krishna. Whoever takes shelter of you has his wishes fulfilled. Bestowing your mercy on him, you make him a resident of Vṛndāvana [the highest heaven]. My desire is that you will also give me a residence in the pleasure groves of Sri Vṛndāvana-dhāma. Thus within my vision I will always behold the beautiful pastimes of Rādhā and Krishna. I beg you to make me a follower of the cowherd damsels of Vraja. Please give me the privilege of devotional service and make me your own maidservant. This very 
fallen and lowly servant of Krishna prays, "May I always swim in the love of Śr̄̄ Śrī Rādhā and Govinda.”

Then devotees, praying constantly, circumambulate Tulsi at least four times. During this time they show their devotion by libating her with spoons of water that are so small that they inhibit overwatering. When the circumambulations end, so does Tulsi's ritual.

It is common to offer loving care to one's biological mother, and devotees ritually do the same for Tulsi. According to The Life of Tulasī Devī and Her Care and Worship, an ISKCON manual for Tulsi practice, Tulsi requires daily cleaning but never with non-organic commercial sprays. Unless pruning can help to heal her, Tulsi should not be pruned, and her leaves cannot be picked on a day following an ekādaśí ritual fast. While picking leaves or buds, with the right hand only, one must recite Tulsi's mantra or sacred phrase, which translates into English as, "O Tulsi, you are born from nectar. You are always very dear to Lord Keshava [Krishna]. Now, in order to worship Lord Keshava, I am collecting your leaves and buds. Please bestow your benediction on me to serve the Lord" (Amala-bhakta Dasa, 1997, p. 79).

In both casual conversations and interviews, devotees unanimously exhibited some measure of spiritual respect for their leafy goddess. Dandavats Dasa, a long-time New Talavana resident, told me that "Tulsi offers healing to the body, healing to our lives, and offers the greatest spiritual benefits. The care and cultivation of Tulsi is essential to our religious practices and observances." Mayapur Dham Dasa told me, "Tulsi is in a class by herself and Krishna loves her so much ... she can bestow pure devotional service upon us. She can give us the ultimate benediction. So she nurtures us like a good mother." I found it striking that in remark after remark devotees, without effort or self-consciousness, addressed Tulsi with the personal human pronoun "she," in contrast to many Americans who routinely refer to plants with the impersonal 
"it." At New Talavana, Tulsi is not just an object that humans can exploit as they wish. Instead, she attracts respect as a valued subject, a person in her own right.

However, it is important to note that veneration of Tulsi did not come easy at first for many devotees who were raised in a EuroAmerican culture that largely does not recognize or promote the worship of sacred plants. Several devotees indicated that at the beginning of their New Talavana spiritual careers, botanical worship felt unfamiliar and uncomfortable. Without their guru Prabhupāda's prodding, they might have given up the practice, but instead, they found themselves, over time, not just habituated to but deeply appreciative of the practice. Devotee Mahindranath told me, "When I first came to the movement, I thought, 'What am I doing? I'm worshipping a plant!' This went through my head for a few months. Then, after some time, I came to very much enjoy doing it because Tulsi is the favorite spice of Lord Krishna." Another devotee, Sanjaya, explained to me that he came to Tulsi slowly, through a string of small spiritual insights, motivated by the thought, "If it's important to Krishna, it's important to me."

Thus, devotee experiences of Tulsi resemble others that I have described at New Talavana. Tulsi remains experienced tensively and liminally, as devotees address Tulsi with pronouns usually reserved for humans alone, yet she also is so unlike humans that at first her worship strikes some people as strange. Because consuming food should be a religious practice and only becomes so with her presence, she may be venerated for her nurturing qualities. Rituals in her honor, including rituals of care, indicate the communal experience of maternal respect that is extended to the green goddess. Finally, devotees express intimacy through praying to her, caring for her, and wearing her around their neck.

\section{Mothers in dialogue}


The ways that devotees approach cows and Tulsi can inform the psychology of religion given that devotees openly regard both natural beings as spiritual mothers. In her liminal relationship with humans, Mother Cow is explicitly defined as one of the important Seven Mothers, and devotees are quick to perceive her that way. Like a good mother, she nurtures New Talavana both spiritually, in terms of enabling essential service to Krishna, and physically, as she supplies the dairy products that nourish the community and make honoring prashadam possible. Devotees feel that just as we wish to pamper and not kill our human mother, so we should offer care, not harm, to our bovine Mother. Thus, New Talavana experiences of cattle resemble those of a good selfobject mother; they arise tensive, liminal, and tinged with themes of nurturance, respect, and intimacy.

There are resemblances to the experience of good maternal selfobjects in the worship of Tulsi, as well. Devotees experience her liminally, as neither-us-nor-not-us, and they believe that like a caring mother she protects us, leads us from sin, sponsors our growth, and enables our activities. Devotees recognize this maternal side in experiencing her as a divine person rather than just a stationary thing. As with Mother Cow, New Talavana religious experiences of Tulsi resonate with those of the maternal selfobject, bearing as they do liminal relationships reflecting themes of nurturance, maternal worthiness of respect, and intimacy.

At the same time, such experiences of maternal natural selfobjects still differ from typical experiences of a biological human mother. No devotees provide their biological mothers with a shed, pasture, and hay like they do cattle, nor do they call veterinarians when their mothers are ill. Because members of this sect generally consider humans to be superior to natural entities, cattle, unlike human mothers, do not attend religious services other than the Festival of the Cow, during which only cows, not human mothers, are constrained within pens. None of the devotees 
offer their biological mothers a greenhouse to winter in, like Tulsi, nor do they ritually eat parts of their biological mothers with every meal. Therefore, New Talavana reveals experiences with sacred maternal natural beings that strongly resemble, yet still diverge from, experiences with human mothers. Cattle and Tulsi may be culturally- and religiously-constructed experiential "persons," but they still are not fully human persons because they are a "special kind of subjective other" (Myers, 2007, p. 11).

Nonetheless, the experiences that I observed at New Talavana provide a challenge to self psychology to expand its notion of the selfobject. Although self psychological theory clearly holds that entities like cattle and plants can serve as selfobjects, most of the self psychological literature focuses prominently on human selfobjects and neglects nonhuman ones. Moreover, much self psychological practice does not consider regard for cattle or bushes as one's mother to reflect psychological health because psychoanalysis does not include the explicit concept of natural beings as persons. As developmental psychologist Gene Myers writes in The Significance of Children and Animals, "Our formalized understandings — our theories — of the self and its context have systematically obscured the importance of other species in our development" (Myers, 2007, p. 5). But, as I have indicated, this limited vision of concepts of the person and the selfobject appears culture-bound. We cannot understand the religious world of New Talavana, or certain other religious life worlds, without accounting for the fact that devotees may have powerful selfobject experiences of natural entities as mothers that are not entirely unlike humans' experiences of their human mothers.

As such, New Talavana spirituality helps the psychology of religion to understand cows, Tulsi plants, and sacred natural persons in a new light. For example, folklorist Alan Dundes (1997, pp. 98-105) employed Freudian theory to explain that Hindu cow veneration arises from 
ambivalent drives directed toward the mother. Because Indian culture stigmatizes oral aggression, Dundes wrote, repressed negative oral drive energy directed at the mother becomes symbolically transmuted into a taboo against eating beef, which comes from the metaphorical mother, the cow. At New Talavana something different is occurring, and this is not just because these Hindus exist within the U. S. rather than Indian cultural environment. By implementing self psychology rather than classical Freudianism, I make Occam happy by discovering a simpler psychoanalytic explanation for cow reverence than Dundes found: New Talavana Hindus reverence Mother Cow as a way of experiencing, embodying, and expressing religion in terms of what commonly supplies the most psychologically fundamental of all relationships, the relationship with the mother. In so doing, their religious experiences with cattle, as with Tulsi, manifest a thematic orientation toward nurturance, respect, and intimacy with regard to sacred natural persons.

This study provides other benefits for the fields of psychology of religion and for pastoral counseling. The selfobject experiences of New Talavana Hindus highlight the importance of methodologically recognizing the possible personhood of nonhuman entities, as without such a recognition, comprehending the religious experiences of practitioners at New Talavana becomes difficult. Moreover, I argue that the concept of the selfobject may be a useful tool in such an exploration, although other tools such as the transitional object may prove fruitful in the future as well. Finally, if we wish to extend compassionate and effective pastoral counseling to all religious seekers, we must be willing to understand that relationships with nonhuman beings that are experienced as holy persons can serve as sources for healing and self-coherence, even if the depths of such healing remain poorly understood. 


\section{References}

Adams, M. (1999). Emily Dickenson had a dog: an interpretation of the human-dog bond. Anthrozoös, 12(3), 132-137. doi: 10.1080/13669877.2012.737822.

Alper, L. S. (1993). The child-pet bond. In A. Goldberg (Ed.), Progress in self psychology, volume 9: The widening scope of self psychology (pp. 257-270). Hillsdale, NJ: Analytic Press.

Amala-bhakta Dasa. (1997). The life of Tulasī Devi and her care and worship. Sandy Ridge, NC: Krishna Productions.

Bekoff, M. (2007). The emotional lives of animals. Novato, CA: New World Library.

Berns, G. (2013). How dogs love us. Boston, MA: New Harvest.

Berry, T. (2006). Prologue: loneliness and presence. In P. Waldau and K. Patton (Eds.), A communion of subjects (pp. 5-10). New York, NY: Columbia University Press.

Brown, S.-E. (2004). The human-animal bond and self psychology: toward a new understanding. Society and Animals, 12(1), 67-86. doi: 10.1163/156853004323029540. . (2007). Companion animals as selfobjects. Anthrozoös, 20(4), 329-343. doi: 10.2752/089279307X245654.

Browning, D. S. (1987). Religious thought and the modern psychologies. Philadelphia, PA: Fortress Press.

Bryant, E. F. (2003). Krishna: The beautiful legend of God. London, England: Penguin Books.

Coward, H. (2000). The ecological implications of karma theory. In L. E. Nelson (Ed.), Purifying the earthly body of God: Religion and ecology in Hindu India (pp. 39-49). New Delhi, India: D. K. Printworld.

Crooke, W. (1912). The veneration of the cow in India. Folklore, 23(3), 275-306. 
de Waal, F. (1996). Good natured: The origins of right and wrong in humans and other animals. Cambridge, MA: Harvard University Press.

Derrida, J. (2008). The animal that therefore I am. New York, NY: Fordham University Press.

Diener, P., Nonini, D., \& Robkin, E. E. (1978). The dialectics of the sacred cow: ecological adaptation versus political appropriation in the origins of India's cattle complex. Dialectical Anthropology, 3(3), 221-241.

Dundes, A. (1997). Two tales of crow and sparrow. Lanham, MD: Rowan and Littlefield.

Freed, S. A., \& Freed, R. S. (1981). Sacred cows and water buffalo in India: the uses of ethnography. Current Anthropology, 22(5), 483-490.

Gadamer, H.-G. (1989). Truth and method. New York, NY: Crossroad.

Haberman, D. L. (1994). Journey through the twelve forests: An encounter with Krishna. New York, NY: Oxford University Press. . (2006). River of love in an age of pollution. Berkeley: University of California Press. . (2013). People trees: Worship of trees in northern India. New York, NY: Oxford University Press.

Hallowell, A. I. (1960). Ojibwa ontology, behavior, and worldview. In S. Diamond (Ed.), Culture in history: Essays in honor of Paul Radin (pp. 19-52). New York, NY: Columbia University Press.

Harris, M. (1966). The cultural ecology of India's sacred cattle. Current Anthropology, 7(1), 5166. . (1974). Cows, pigs, wars, and witches. New York, NY: Random House.

Heston, A. (1971). An approach to the sacred cow of India. Current Anthropology, 12, 191-209. 
Holliman, P. J. (2002). Religious experience as selfobject experience. In A. Goldberg (Ed.), Postmodern self psychology: Progress in self psychology (Vol. 18) (pp. 193-205). Hillsdale, NJ: Analytic Press.

Jha, D. N. (2002). The Myth of the Holy Cow. London: Verso.

Kinsley, D. R. 1977. The Sword and the Flute. Berkeley: University of California Press.

Kohut, H. (1971). The Analysis of the Self. New York: International Universities Press, Inc. . (1991). The Search for the Self (Vol. 4). Madison, CT: International Universities Press, Inc.

Korom, F. J. (2000). Holy cow! The apotheosis of Zebu, or why the cow is sacred in Hinduism. Asian Folklore Studies, 59(2), 181-203.

Lodrick, D. O. (1981). Sacred cows, sacred places: Origins and survivals of animal homes in India. Berkeley: University of California Press. . (2005). Symbol and sustenance: cattle in South Asian culture. Dialectical Anthropology, 29(1), 61-84.

Melson, G. M. (2001). Why the wild things are. Cambridge, MA: Harvard University Press. Myers, G. (2007). The significance of children and animals. West Lafayette, IN: Purdue University Press.

Prabhupāda, S. (1970). The Nectar of Devotion. Los Angeles, CA: Bhaktivedanta Book Trust. . (1971). Krṣna. Los Angeles, CA: Bhaktivedanta Book Trust. . (1986). Bhagavad-gìtā as it is. Los Angeles, CA: Bhaktivedanta Book Trust. . (2014a, August). Caitanya Caritāmrta. Bhaktivedanta VedaBase http://vedabase. com/cc/madhya/17/en. 
__. (2014b, September). Śrimad Bhāgavatam. Bhaktivedanta VedaBase http://vedabase. $\mathrm{com} / \mathrm{sb} / 10 / 21 / \mathrm{en}$.

Schlauch, C. R. (1999). Rethinking selfobject and self: implications for understanding and studying religious matters. Pastoral Psychology, 48(1), 57-78. doi: 10.1023/A:1021906813067.

Turner, V. (1969). The ritual process. Ithaca, NY: Cornell University Press.

Upadhyaya, K. D. (1964). Indian botanical folklore. Asian Folklore Studies, 23(2), 15-34.

Wolf, E. S. (1988). Treating the self: Elements of clinical self psychology. New York, NY: Guilford Press.

Zeiler, X. (2013). Benevolent bulls and baleful buffalos: male bovines versus the 'holy cow' in Hinduism. In C. Deane-Drummond, R. Artinian-Kaiser, \& David L. Clough (Eds.), Animals as religious subjects (pp. 125-147). London, England: Bloomsbury T\&T Clark. 